\title{
NASELJAVANJE VELIKE SJENICE (Parus major L.) U MLADE BJELOGORIČNE SASTOJINE POMOĆU ŠKRINJICA ZA GNIJEŽĐENJE
}

\author{
NESTBOX OCCUPANCY BY THE GREAT TIT (Parus major L.) \\ IN YOUNG DECIDUOUS FOREST STANDS
}

\author{
Zdravko DOLENEC
}

\begin{abstract}
SAŽETAK
U gospodarenju i upravljanju šumama sve se više nameće kao prioritetno pitanje očuvanje bioraznolikosti šumskih ekosustava. Ptice imaju značajnu ulogu u cjelokupnosti živoga svijeta šuma, primjerice, kao važna sastavnica hranidbenih lanaca. Recentna istraživanja diljem mnogih regija svijeta upućuju na pad populacija i bogatstva šumskih ptičjih vrsta, a to se posebice odnosi na ptice koje se gnijezde u dupljama šumskog drveća. Poseban je naglasak na sekundarnim dupljašicama. Za razliku od primarnih ptica dupljašica koje same dube šupljine u drvetu (deblu ili granama), sekundarne dupljašice za gniježđenje koriste duplje primarnih dupljašica ili duplje nastale prirodnim propadanjem drveta. Da bi se održala raznolikost ptičjeg svijeta u šumama bez dovoljno duplji za reprodukciju, u sve se više zemalja pristupa postavljanju umjetnih duplji (škrinjica). To se ponajviše odnosi na mlade bjelogorične, crnogorične i monokulturne sastojine te područja pošumljena egzotičnim vrstama. U ovome se radu analizira jedno takvo vješanje škrinjica u mladoj bjelogoričnoj šumi. Neka istraživanja sugeriraju da u nekih vrsta ptica u naseljavanju škrinjica određenu važnost ima obojenost te visina škrinjica iznad tla. U ovome istraživanju ukupno je postavljeno 120 standardnih drvenih škrinjica (60 zeleno obojenih i 60 smeđe obojenih) za veliku sjenicu (Parus major). Škrinjice su vješane u parovima na pojedino drvo, na visinu 4,0 - 4,5 m (,visoko“) i 2,0 - 2,5 m („nisko“). Na prvom bi drvetu „zelena“ bila na poziciji „,visoko“, na drugom drvetu na poziciji „nisko“ i tako redom. Cilj ovog rada bio je utvrditi stupanj prihvaćanja škrinjice s obzirom na obojenost te poziciju na drvetu. Od 60 parova škrinjica naseljene su 44 (73,3\%). Od para škrinjica na drvetu ptice bi naselile samo jednu zbog intrai interspecijske kompeticije. Od 44 naseljene škrinjice velika sjenica naselila je $35(79,5 \%)$, a plavetna sjenica (Cyanistes caeruleus) devet (20,5\%). Velika je sjenica najvećim dijelom naselila „zelene“ škrinjice (88,6\%) dok s obzirom na poziciju škrinjica na drvetu nije bilo značajne razlike. Zaključno, tijekom naseljavanja škrinjica boja ima prednost u odnosu na poziciju škrinjice na drvetu.
\end{abstract}

KLJUČNE RIJEČl: velika sjenica, Parus major, sekundarne ptice dupljašice, naseljavanje škrinjica za gniježđenje, mlade bjelogorične sastojine

\section{UVOD}

\section{INTRODUCTION}

Sve veći broj autora posljednjih desetljeća sugerira da se promjenama unutar pojedinih šumskih ekosustava narušava njihova bioraznolikost (npr. Kouki i sur. 2001), gdje ptice pokazuju posebnu osjetliivost (npr. Edenius i Elmberg 1996). Često se u tom kontekstu spominju vrste koje savijaju gnijezda u dupljama - ptice dupljašice. Obično ih dijelimo na primarne i sekundarne dupljašice. Primarne dupljašice same dube duplje u drvetu kako bi u njima 


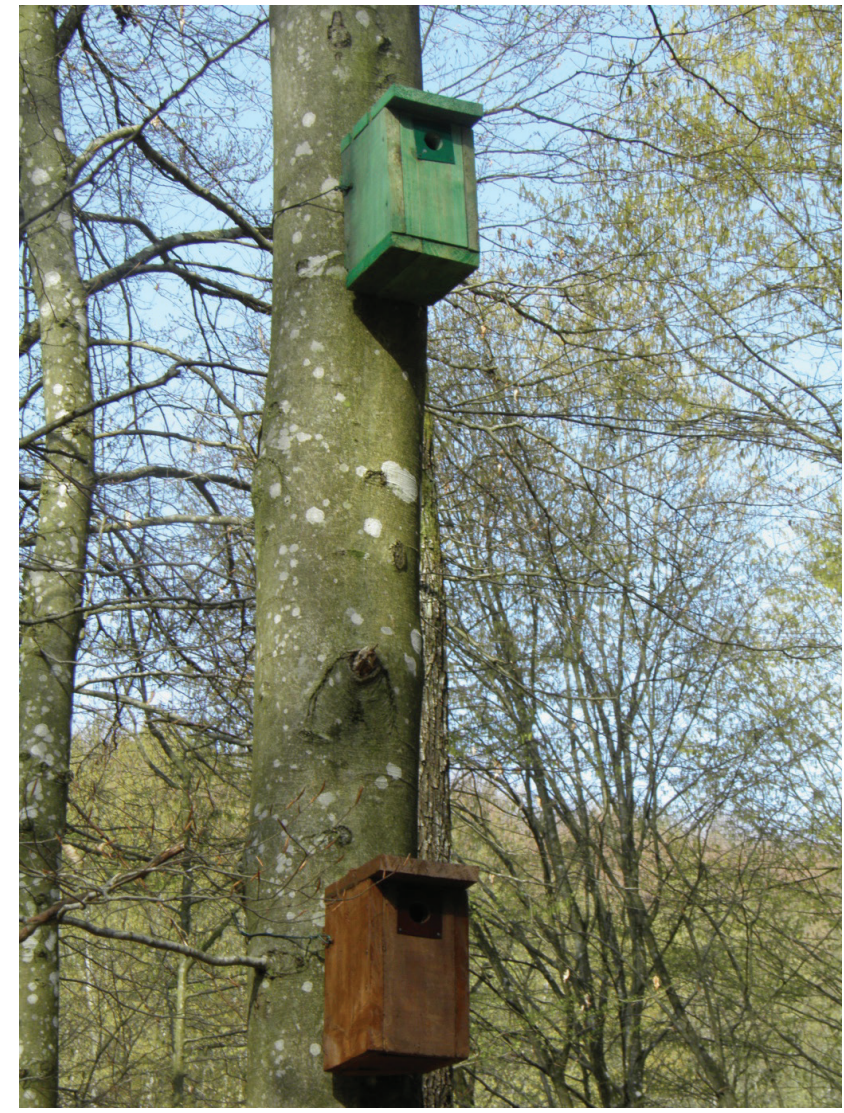

Slika 1. Položaj škrinjica na drvu (Snimio: Z. Dolenec)

Figure 1. Nestboxes position on the tree (Photo: Z. Dolenec)

gnijezdile (npr. veliki djetlić Picoides major, Kotaka i Matsuoka 2002), dok sekundarne dupljašice koriste već izdubljene duplje ili šupljine nastale postupnim propadanjem (truljenjem) drveta, bilo debla ili grana. U našim kontinentalnim šumama među najčešćim sekundarnim dupljašicama su ptice iz porodice sjenica, Paridae. Općenito u svijetu, obligatnim dupljašicama šuma pripada $30-45 \%$ vrsta ptica (Blanc i Martin 2012). Niska brojnost duplji posljednjih desetljeća u šumama mnogih europskim zemalja (Newton 1994) uzrokom je pada populacija mnogih sekundarnih dupljašica (npr. Aitken i Martin 2008). To se dijelom pripisuje i prijelazu iz tradicionalnog gospodarenja šumama na intenzivno (npr. Bradshaw 2004).

Ovo je istraživanje usmjereno na neka obilježja naseljavanja škrinjica velikom sjenicom (Parus major L.), malom monogamnom pjevicom i pticom stanaricom iz reda vrapčarki (Passeriformes) u mladoj bjelogoričnoj šumi na području sjeverozapadne Hrvatske (sjeverne padine gore Medvednice). Godišnje se gnijezdi jednom ili dvaput. Istraživana vrsta rado prihvaća ponuđene škrinjice za gniježđenje (npr. Dolenec i sur. 2005). Osim velike sjenice, vrste koje mogu naseliti škrinjice tipa „Parus major“ na području istraživanja ponajprije su plavetna sjenica (Cyanistes caeruleus), crnoglava sjenica (Poecile palustris) te brgljez (Sitta europaea). Spomenute sekundarne dupljašice u većem ili manjem broju nalazimo na gniježđenju u bjelogoričnim šumama sjeverozapadne Hrvatske (npr. Kirin i sur. 2011) kao i u šumama mnogih europskih zemalja (npr. Rossi de Gasperis i sur. 2016).

Cilj ovog rada je istražiti naseljenost škrinjica tipa „Parus major" velikom sjenicom, odnosno utvrditi stupanj naseljenosti s obzirom na vanjsku obojenost škrinjica te poziciju škrinjica s obzirom na visinu vješanja iznad tla na deblu, kako bi u budućnosti bila što učinkovitija njihova primjena u očuvanju bioraznolikosti naših mladih bjelogoričnih sa-

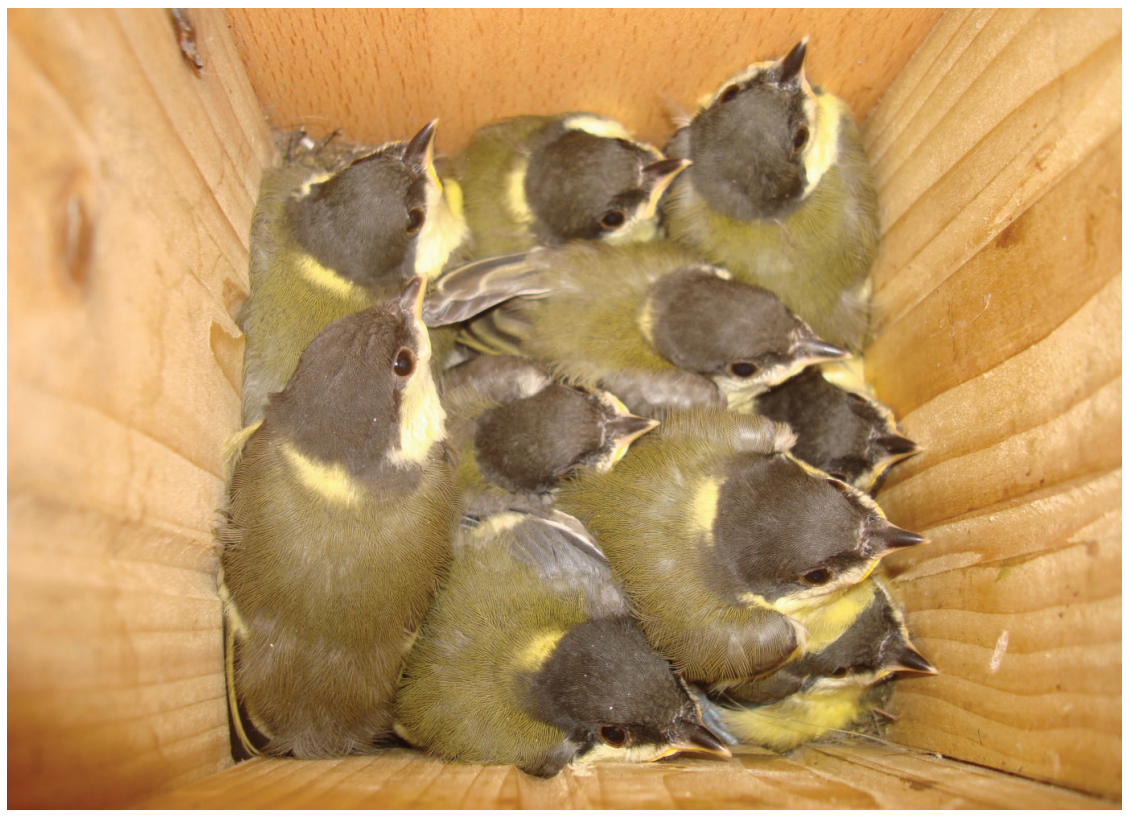

Slika 2. Mlade velike sjenice (Parus major) u škrinjici (Snimio: Z. Dolenec)

Figure 2. Young Great Tits (Parus major) in nestbox (Photo: Z. Dolenec) 
stojina. Apel za očuvanje i zaštitu ptica, između ostalog, naglašava važnost postavljanja škrinjica (npr. Minot i Perrins 1986, Kiss i sur. 2017) kao jedan od načina pomoći sekundarnim dupljašicama koje su značajne karike hranidbenih lanaca unutar ekoloških mreža šumskih ekosustava. Često ptice dupljašice koriste škrinjice i za noćenje ili kao zaklon (npr. Drent 1987).

\section{MATERIJAL I METODE MATERIAL AND METHODS}

U ovom se radu istraživalo naseljavanje (zauzimanje) drvenih škrinjica (umjetnih duplji) vrstom velika sjenica postavljenih u mladoj bjelogoričnoj sastojini koja administrativno pripada naselju Strmec Stubički (4557’N, 1554'E; 191 m nadmorske visine), sjeverozapadna Hrvatska. Sastojina pripada šumskoj zajednici hrasta kitnjaka i običnog graba (As. Epimedio-Carpinetum betuli / Horvat 1938 / Borhidi 1963.) (izvor: Vukelić i sur. 2008). Dominantna vrsta istraživanog područja je obična bukva (Fagus silvatica) zbog hladnijeg, strmijeg i zatvorenijeg položaja, a rjeđe se pojavljuje hrast kitnjak (Quercus petrea) i obični grab (Carpinus betulus). Ostale šumske sastojine nisu bila obuhvaćena istraživanjem budući da sekundarne dupljašice različito reagiraju na ponuđene škrinjice u različitim šumskim područjima (npr. Sanz 1998., Mänd i sur. 2009., Da Silva i sur. 2012). Istraživanje je obavljeno samo jedne godine i to u sezoni gniježđenja 2018. godine (ožujak-srpanj) kako bi ptice gnjezdarice bile izložene istim abiotičkim i biotičkim ekološkim čimbenicima, budući da se oni dijelom mijenjaju od godine do godine (npr. Pasinelli 2001). Sve su škrinjice bile istih dimenzija kako bi se izbjeglo da različitost dimenzija utječe na gniježđenje, kako je to dokazano za neke sekundarne dupljašice (npr. Karlsson i Nilsson 1977, Moeed i Dawson 1979, Lowther 2012). Škrinjice su bile tipa „Parus major“, izrađene od dasaka debljine $2,5 \mathrm{~cm}$, unutarnjih dimenzija $12 \times 12 \times 22 \mathrm{~cm}$ (unutarnje dno $144 \mathrm{~cm}^{2}$ ) te izvana premazane sredstvom za zaštitu od truljenja („Sadolin“) zelene (60 škrinjica) i smeđe boje (60 škrinjica). Okrugli otvor za ulaz ptica (uletalo) bio je promjera $3,2 \mathrm{~cm}$, a gornja pomična daska („krov“) omogućava jednostavni pristup gnijezdu. Zahvaljujući jednostavnom pristupu gnijezdu škrinjice se često koriste za razna istraživanja ptičjeg svijeta (npr. Dolenec i sur. 2008., Dolenec i sur. 2011a, Dolenec i sur. 2011b, Kocijan i sur. 2014., Miño and Massoni 2017). Škrinjice su imale na uletalu pribijenu metalnu pločicu (boje škrinjice), koja je u sredini imala okrugli otvor istih dimenzija kao i ulaz u škrinjicu. Time je spriječeno proširenje uletala od strane drugih ptica (ponajprije djetlića Picoides spp.) i time znatno spriječen pristup predatora gnijezdu. Na području istraživanja po prvi put su postavljane škrinjice ovoga tipa, čime su izbjegnute eventualno stečene navike ptica, odnosno usvojeno iskustvo iz prethodnih godina u odabiru škri- njica. Prema Mazgajskom (2003), stara gnijezda ili ostaci starih gnijezda čine unutarnji volumen manjim (pliće dno), pa su buduća jaja i čučavci u škrinjicama više izloženi predatorima. Usto, stara su gnijezda u pravilu pogodno obitavalište raznih ektoparazita koji mogu izravno utjecati na reproduktivni uspjeh (npr. Rendel i Verbeek 1996). Stoga su u ovom istraživanju korištene samo novo izrađene škrinjice od dasaka. Ponuđene su samo klasične drvene škrinjice. jer prema nekim autorima (npr. García-Navas i sur. 2008, Bueno-Enciso i sur. 2016) škrinjice izrađene iz različitog materijala često imaju značajno različiti postotak naseljavanja. Nadalje, istraživanja naseljavanja škrinjica velikom sjenicom u Velikoj Britaniji pokazala su da orijentacija ulaza (uletala) prema stranama svijeta utječe na njihovo zauzimanje. Rezultati tih istraživanja pokazali su slabije naseljavanja škrinjica koje imaju ulaz u smjeru jug-jugozapad (Goodenough i sur. 2008a, Goodenough i sur. 2008b). Stoga su u ovome radu pomoću kompasa sve škrinjice bile usmjerene prema istoku, kako spomenuti čimbenik ne bi utjecao na rezultate. Škrinjice su na debla postavljana u parovima (jedna zeleno i jedna smeđe obojana) tijekom mjeseca listopada 2017. godine na različite visine iznad tla (Slika 1). Jednom bi „zelena“ bila niže, na drugom drvetu „smeđa“ $i$ tako redom. Od 60 zeleno obojenih, 30 je bilo na drvetu u položaju ,visoko“ (4,5 m iznad tla) te 30 škrinjica na poziciji „nisko“ (2,5 m iznad tla). To isto se odnosi na smeđe obojene (ukupno postavljeno 120 škrinjica). Na jedan par postavljenih škrinjica očekivao se jedan par ptica na gniježđenju zbog kompeticije s istom vrstom ili sa drugim vrstama sekundarnih dupljašica. Škrinjica se smatrala naseljenom ako je ženka počela s inkubacijom. Udaljenost između pojedinih parova škrinjica iznosila je oko $40 \mathrm{~m}$. Statistička obrada dobivenih podataka sa terena obavljana je pomoću statističkog paketa SPSS 17.0, a dobiveni rezultati smatrali su se signifikantnim ako je p-vrijednost bila manja od 0,05.

\section{REZULTATI RESULTS}

Od ukupno 60 parova škrinjica smještenih na 60 stabala naseljene su 44 škrinjice $(73,3 \%)$. Od tog broja 35 je naselila velika sjenica $(79,5 \%)$ dok je ostalih devet škrinjica $(20,5$ $\%)$ naselila plavetna sjenica. Od spomenutih 35 škrinjica naseljenih velikom sjenicom (Slika 2) samo četiri su pripadale „smeđim“ (11,4\%) dok je u „zelenim“ škrinjicama gnijezdio 31 par (88,6\%), što ukazuje na značajnu statističku razliku s obzirom na obojenost $\left(\chi^{2}=20.82, \mathrm{df}=1, \mathrm{p}<\right.$ 0.001). Međutim, s obzirom na položaj škrinjica na deblu nije bilo statistički značajne razlike u odabiru škrinjica. Od spomenutih 35 naseljenih škrinjica 19 (54,3\%) gnijezda je bilo „visoko“ te $16(45,7 \%)$ „nisko“ ( $\chi^{2}=0.61, \mathrm{df}=1, \mathrm{p}=$ 0.612). Obilježja devet naseljenih škrinjica plavetnom sje- 
nicom nisu analizirana zbog malog uzorka. Također zbog malog uzorka nije analizirano drugo gniježđenje velike sjenice, jer je drugom gniježđenju pristupilo samo osam parova, što je 20,4\% u odnosu na broj parova prvog gniježđenja, a što znači da je svaki peti par pristupio ponovnom gniježđenju. Plavetne sjenice imaju na istraživanom području godišnje samo jedno gniježđenje. Unatoč intra- i interspecijskoj kompeticiji, na jednom drvetu bile su zauzete obje škrinjice, „visoku“ „zelenu“ naselila je velika sjenica, a "nisku“ „smeđu“ plavetna sjenica. Obje su vrste uspješno othranile mlade ptice. Kod šest parova škrinjica bilo je unošenja materijala u obje škrinjice na istom deblu, ali je samo jedan, dominantniji par velikih sjenica uspješno gnijezdio, dok je drugi par napustio daljnju gradnju gnijezda ili prestao s daljnjom nesidbom jaja. U sedam nenastanjenih škrinjica pticama svoj prostor za razmnožavanje našli su kukci. Dvije je zauzeo europski stršljen (Vespa crabro L.), a u pet su bili mravi (Formicidae).

\section{RASPRAVA I ZAKLJUČAK DISCUSSION AND CONCLUSION}

Unatoč velikom broju znanstvenih članaka još uvijek su nam manjkava znanja o mjestu i ulozi pojedinih vrsta živih bića šumskih ekosustava, a to se značajnim dijelom odnosi i na bogatstvo ptičjih vrsta te gustoću njihovih populacija i to posebice u kontekstu očuvanja bioraznolikosti (npr. GilTena i sur. 2007). Brojnost pogodnih duplji za gniježđenje $\mathrm{u}$ šumama važna je varijabla koja utječe na prisutnost i bogatstvo ptičjih vrsta te brojnost ptičjih parova unutar pojedine vrste u razdoblju gniježđenja sekundarnih dupljašica (npr. Robles i sur. 2012, Redolfi De Zan i sur. 2016). Mnogi autori sugeriraju na važnost očuvanja prirodnih duplji u drveću, sa svrhom očuvanja ptičjeg svijeta u šumama kao važne sastavnice „zdravih“ šumskih ekosustava (npr. Newton 1994). Međutim, u pravilu, u mladim šumskim sastojinama broj duplji u drveću je mali, pa je stavljanje „umjetnih duplji“ u takva staništa omogućeno održavanje bogatstva sekundarnih dupljašica, kao i gustoće populacija na željenoj razini. Prema Lõhmusu i Remmu (2005), u starim šumskim sastjinama Estonije velika je sjenica radije gnijezdila u škrinjicama nego u prirodnim dupljama, vjerojatno zbog njihovih povoljnih dimenzija. Primjerice, škrinjice pružaju pticama veću zaštitu od predatora (npr. Møller 1989) i reproduktivno su uspješnije u odnosu na prirodne duplje (npr. Purcell i sur. 1997). Postavljanje ,umjetnih duplji“" u šumska staništa zakonski je regulirano kod više europskih zemalja (npr. Mänd i sur. 2005). Škrinjice bi ponajviše trebalo stavljati u mlade bjelogorične i crnogorične sastojine, kao i šumske kulture i plantaže zbog nedostatka dovoljnog broja prirodnih duplji u odnosu na povoljni hranidbeni kapacitet tih šuma (ponajprije gusjenica) u razdoblju gniježđenja (npr. Newton 1998, Robles i sur. 2011).
Naseljenost škrinjica tijekom ovog istraživanja u mladoj bjelogoričnoj šumi podno sjevernih padina Medvednice tijekom reproduktivne sezone 2018. godine iznosila je 73,3\%, što je slično kao i u nekim drugim šumskim područjima Europe. Primjerice, Leniowski i Węgrzyn (2013) spominju $78 \%$-tnu nastanjenost škrinjica tipa „Parus major“, a Kudelska i sur. (2017) navode 64\%-tnu. Rezultati ovog istraživanja sugeriraju prednost zeleno obojenih škrinjica u odnosu na smeđe, dok njihova pozicija na deblu nije od posebne važnosti. Slične podatke o gniježđenju sjenica koji idu u prilog „zelenim“ škrinjicama navodi u svome radu Browne (2006). Posljednjih desetljeća ima sve više dokumentiranih podataka o padu brojnosti populacija sve većeg broja ptičjih vrsta, među kojima su i brojne sekundarne dupljašice (npr. Fuller i sur. 2005). Tu treba spomenuti i sve veći utjecaj klimatskih promjena na ptičji svijet, posebice na njihovu fenologiju kako u svijetu (Charmantier i sur. 2008, Bauer 2010, Källander i sur. 2017) tako i u Hrvatskoj (Dolenec i Dolenec 2011, Dolenec 2017, Dolenec 2018). To su samo neki od problema s kojima se danas suočava ornitofauna. Očuvanje i zaštita sekundarnih ptica dupljašica pomoću škrinjica za gniježđenje sve se više naglašava kao važna sastavnica očuvanja bioraznolikosti u mnogim zemljama. Preliminarno istraživanje prezentirano u ovome radu sugerira postavljanje zeleno obojenih škrinjica. Potrebna su daljnja istraživanja, ponajprije ornitoloških i šumarskih institucija i ustanova o potrebi vješanja škrinjica u pojedinim šumskim sastojinama, dok bi u praktičnoj realizaciji vješanja škrinjica bilo poželjno uključenje npr. prirodoslovnih udruga i školske populacije s naglaskom interdisciplinarnog pristupa (Dolenec i Dolenec 2013), kako bi mladi naraštaji izravno doprinijeli očuvanju i zaštiti šumskih ptica te u konačnici spoznali važnost ispravnog pristupa suživotu čovjeka i prirode.

\section{LITERATURA} REFERENCE

- Aitken, K. E. H., K. Martin, 2008: Resource selection plasticity and community responses to experimental reduction of a critical resource. Ecology, 89: 971-980.

- Bauer, Z., M. Trnka, J. Bauerová, M. Možný, P. Štěpánek, L. Bartošová, Z. Žalud, 2010: Changing climate and the phenological response of great tit and collared flycatcher populations in floodplain forest ecosystems in Central Europe. Int. J. Biometeorol., 54: 99-111.

- Blanc, L. A., K. Martin, 2012: Identifying suitable woodpecker nest trees using decay selection profiles in trembling aspen ( $P o p$ ulus tremuloides). For. Ecol. Manage., 286, 192-202.

- Bradshaw, R., 2004: Past anthropogenic influence on European forests and some possible genetic consequences. For. Ecol. Manage., 197: 203-212.

- Browne, S. J., 2006: Effect of nestbox construction and colour on the occupancy and breeding success of nesting tits Parus spp. Bird Study, 53: 187-192. 
- Bueno-Enciso, J., E. S. Ferrer, R., Barrientos, J. J. Sanz, 2016: Effect of nestbox type on the breeding performance of two secondary hole-nesting passerines. J. Ornithol., 157:759-772.

- Charmantier, A., R. H. McCleery, L. R. Cole, C. M. Perrins, L. E. B. Kruuk, B. C. Sheldon, 2008: Adaptive phenotypic plasticity in response to climate change in a wild bird population. Science, 320: 800-803.

- Da Silva L. P., J. Alves, A. A. Da Silva, J. A., Ramos, C. Fonseca, 2012: Variation in the abundance and reproductive characteristics of Great Tits Parus major in forest and monoculture plantations. Acta Ornithol., 47: 147-155.

- Dolenec, P., I. Kocijan, Z. Dolenec, 2011a: Intra-seasonal changes in reproductive strategy of a multi-brooded passerine: the tree sparrow Passer montanus. Ethology Ecology and Evolution, 23: 368-374.

- Dolenec, Z., 2017: Advances in arrival date of the Common Cuckoo (Cuculus canorus L.) in the forest of northwestern Croatia. Šumarski list, 141 (11-12): 467-475. (In Croatian with English summary)

- Dolenec, Z., 2018: Results of long-term monitoring of timing of laying in deciduous forest Blue Tit (Cyanistes caeruleus L.) in northwestern Croatia. Šumarski list 142 (7-8): 381-386. (In Croatian with English summary)

- Dolenec, Z., P. Dolenec, 2011: Influence of the local spring warming on the breeding phenology in blackcap (Sylvia atricapilla) in Croatia. J. Environ. Biol., 35: 625-627.

- Dolenec, Z., P. Dolenec, 2013: Correlation in Teaching Biology and Geography. Croatian Journal of Education - Hrvatski časopis za odgoj i obrazovanje, 15(Sp.Ed.No.2): 267-274.

- Dolenec, Z., M. Mrakovčić, A. Delić, 2005: Egg dimensions of the Great Tit (Parus major L.) in Croatia. Pol. J. Ecol., 53: 143-145.

- Dolenec, Z., P. Dolenec, A. P. Møller, 2011 b: Warmer springs, laying date and clutch size of tree sparrows Passer montanus in Croatia. Current Zoology, 57: 414-418.

- Dolenec, Z., J. Kralj, P. Mustafić, P. Dolenec, 2008: Female characteristics and egg dimensions of the Starling (Sturnus vulgaris L.) in Croatia. Pol. J. Ecol., 56: 545-548.

- Drent, P. J., 1987: The importance of nestboxes for territory settlement, survival and density of the Great Tit. Ardea, 75: 59-71.

- Edenius, L., Elmberg, J., 1996: Landscape level effects of modern forestry on bird communities in North Swedish boreal forests. Landscape Ecology. 11, 325-338.

- Fuller, R. J., D. G. Noble, K. W. Smith, D. Vanhinsbergh, 2005: Recent declines in populations of woodland birds in Britain: a review of possible causes. Br. Birds, 98: 116-143.

- García-Navas, V., L. Arroyo, J. J.Sanz, M. Díaz, 2008: Effect of nest box type on occupancy and breeding biology of tree sparrows Passer montanus in central Spain. Ibis, 150: 356-364.

- Gil-Tena, A., S. Saura, L. Brotons, 2007: Effects of forest composition and structure on bird species richness in a Mediterranean context: Implications for forest ecosystem management. For. Ecol. Manage., 242: 470-476

- Goodenough, A. E., D. P. Maitland, A. G. Hart, S. L. Elliot, 2008a: Nestbox orientation: a species-specific influence on occupation and breeding success in woodland passerines. Bird Study, 55: 222-232.

- Goodenough, A. E., A. G. Hart, S. L. Elliot, 2008b: Variation in offspring quality with cavity orientation in the great tit. Ethology Ecology and Evolution, 20: 375-389.

- Källander, H., D. Hasselquist, A. Hedenström, A. Nord, H. G. Smith, J-Ĺ. Nilsson, 2017: Variation in laying date in relation to spring temperature in three species of tits (Paridae) and pied flycatchers Ficedula hypoleuca in southernmost Sweden. J. Avian Biol., 48: 83-90.

- Karlsson, J., S. G. Nilsson, 1977: The influence of nest-box area on clutch size in some hole-nesting passerines. Ibis, 119: 207-211.

- Kirin, T., J. Kralj, D. Ciković, Z. Dolenec, 2011: Habitat selection and similarity of the forest songbird communities in Medvednica and Žumberak - Samoborsko gorje nature parks. Šumarski list, 135 (9-10): 467-475.

- Kiss, O., B. Tokody, T. Ludnai, C. Moskát, 2017: The effectiveness of nest-box supplementation for the conservation of European rollers (Coracias garrulus). Acta Zool. Acad. Sci. H., 63: 123-135.

- Kocijan, I., P. Dolenec, Z. Dolenec, A. Radović, 2014: Resource allocation within the replacement clutch: do female European starling (Sturnus vulgaris) adjust their reproductive strategy after a full clutch loss? Current Science, 107: 1597-1601.

- Kotaka, N., S. Matsuoka, 2002: Secondary users of Great Spotted Woodpecker (Dendrocopos major) nest cavities in urban and suburban forest in Sapporo City Japan. Ornithol. Sci., 1: 117-122.

- Kudelska, K., P. Podkowa, K. Karaśkiewicz, A. Surmacki, 2017: Znaczenie skrzynek lęgowych dla ptaków obszarów leśnych na przykładzie Wielkopolskiego Parku Narodowego. Sylwan, 161: 949-957.

- Kouki, J., S. Lofman, P. Martikainen, S. Rouvinen, A. Uotila, 2001: Forest fragmentation in Fennoscandia: Linking habitat requirements of wood-associated threatened species to landscape and habitat changes. Scandinavian Journal of Forest Research, 16(sup003): 27-37.

- Leniowski, K., E. Węgrzyn, 2013: Zasiedlenie poszczególnych typów budek lęgowych w lesie sosnowym - ocena efektywności kompensacji przyrodniczej względem różnych gatunków ptaków. Sylwan, 157: 854-859.

- Lõhmus, A., J. Remm, 2005: Nest quality limits the number of hole-nesting passerines in their natural cavity-rich habitat. Acta Oecologia, 27: 125-128.

- Lowther, P. E., 2012: Does Nest-box Size Impact Clutch Size of House Sparrows? Wilson J. Ornithol., 124: 384-389.

- Mänd, R., V. Tilgar, A. Lhmus, A. Leivits, 2005: Providing nest boxes for hole-nestling birds - Does habitat matter? Biodivers. Conserv., 14: 1823-1840.

- Mänd, R., A. Leivits, M. Leivits, N. L. Rodenhouse, 2009: Provision of nestboxes raises the breeding density of Great Tits Parus major equally in coniferous and deciduous woodland. Ibis, 151: 487-492.

- Mazgajski, T. D., 2003: Nest site choice in relation to the presence of old nests and cavity depth in the starling Sturnus vulgaris. Ethology Ecology and Evolution, 15: 273-281.

- Miño, C. I., V. Massoni, 2017: Sexual differences in the effect of previous breeding performance on nest-box reuse and mate retention in White-rumped Swallows (Tachycineta leucorrhoa). Emu-Austral Ornithol., 117: 130-140.

- Minot, E. O., C. M. Perrins, 1986: Interspecific interference competition - nest sites for blue and great tits. J. Anim. Ecol., 50: 375385.

- Moeed, A., D. G. Dawson, 1979: Breeding of starlings (Sturnus vulgaris) in nest boxes of various types. New Zeal. J. Zool., 6: 613-618.

- Møller, A. P., 1989: Parasites, predators and nest boxes: facts and artefacts in nest box studies of birds? Oikos, 56: 421-423. 
- Newton, I., 1994: The role of nest sites in limiting the numbers of hole-nesting birds: a review. Biological Conservation, 70: 265276.

- Newton, I., 1998: Population Limitation in Birds. Academic Press, London.

- Pasinelli, G., 2001: Breeding performance of the Middle Spotted Woodpecker Dendrocopos medius in relation to weather and territory quality. Ardea, 89: 353-361.

- Purcell, K. L., J. Verner, L.W. Oring, 1997: A comparison of the breeding ecology of birds nesting in boxes and tree cavities. Auk, 114: 646-656.

- Redolfi De Zan L., S. Rossi de Gasperis , L. Fiore, C. Battisti, G. M. Carpaneto, 2017: The importance of dead wood for holenesting birds: a two years study in three beech forests of central Italy. Isr. J. Ecol. Evol., 63: 19-27.

- Rendel, W. B., N. A. Verbeek, 1996: Are avian ectoparasites more numerous in nest boxes with old nest material? Canadian Journal of Zool., 74: 1819-1825.
- Robles, H., C. Ciudad, E. Matthysen, 2011: Tree-cavity occurrence, cavity occupancy and reproductive performance of secondary cavity-nesting birds in oak forests: the role of traditional management practices. For. Ecol. Manage., 261: 1428-1435.

- Robles, H., C. Ciudad, E. Matthysen, 2012: Responses to experimental reduction and increase of cavities by a secondary cavitynesting bird community in cavity-rich Pyrenean oak forests. For. Ecol. Manage., 277: 46-53.

- Rossi de Gasperis, S., L. Redolfi De Zan, C. Battisti, I. Reichegger, G. M. Carpaneto, 2016: Distribution and abundance of hole-nesting birds in Mediterranean forests: impact of past management patterns on habitat preference. Ornis Fennica, 93: 100-110.

- Sanz, J. J., 1998: Effects of geographic location and habitat on breeding parameters of great tits. Auk, 115: 1034-1051.

- Vukelić, J., S. Mikac, D. Baričević, D. Bakšić, R. Rosavec, 2008: Šumska staništa i šumske zajednice u Hrvatskoj. Nacionalna ekološka mreža. Državni zavod za zaštitu prirode, Zagreb. 263 pp.

\section{SUMMARY}

Conservation of the biodiversity of the forest ecosystems is becoming one of the priority issues in the forest management. Birds play an important role in the overall life of the forest ecosystem, for instance, as an important component of the trophic chains. Recent studies worldwide suggest decline in the population size and richness of the forest bird species, especially those nesting in the cavity of the forest trees. Special emphasis is placed on the secondary cavity nesters. In contrast to the primary cavity excavators, which are making a tree cavity by themselves, secondary cavity nesters for their nesting use cavities made by the primary cavity excavators or natural cavities formed by gradual wood decay process. In order to maintain bird diversity in the forests with a lack of nesting cavities, installation of the nestboxes is an important strategy in many countries. This applies mainly to young deciduous, coniferous stands, and monocultural plantations and areas afforested with exotic tree species. In this paper, occupation of the nestboxes in the young deciduous stands was investigated. According to some researchers, the colour of the nestbox and its height above the ground could be important factors of the nestbox occupation in some bird species. In this study, a total of 120 standard wooden nestboxes were used (60 green and 60 brown). Nestboxes were installed in pairs on a single tree, at a height of 4.0 to $4.5 \mathrm{~m}$ ("high" position) and 2.0 to $2.5 \mathrm{~m}$ ("low" position). On the first tree, the green nestbox was in the "high" position, on the next tree in the "low" position and so on. The aim of this study was to determine the degree of occupancy of the nestboxes with a respect to the colour and the position on the tree. Because of the intra- and interspecific competition, only one of the nestbox pair was inhabited. Of the total 60 nestbox pairs, 44 (73.3\%) nestboxes were occupied; 35 (79, 5\%) by a Great Tit (Parus major) and 9 (20.5\%) by a Blue Tit (Cyanistes caeruleus). Great Tits occupied mainly "green" nestboxes $(88.6 \%)$, with no significant differences in the height position of the chosen nestbox. In conclusion, the colour of the nestboxes is more important factor than the height position on the tree during the occupation of the nestboxes by a Great Tit.

KEY WORDS: Great Tit, Parus major, secondary cavity nesters, nest-box occupation, young deciduous forest 